\title{
Loteprednol Etabonate for the Treatment of Dry Eye Disease
}

\author{
Kenneth Beckman, ${ }^{1,2}$ James Katz, ${ }^{3}$ Parag Majmudar, ${ }^{4}$ and Audrey Rostov ${ }^{5}$
}

\begin{abstract}
Dry eye disease (DED) is a common ocular condition that can impair vision and may adversely impact quality of life. Due to the inflammatory nature of this disorder, topical corticosteroids are an effective treatment option, particularly for moderate-to-severe DED when first-line treatments, such as ocular lubricants, are insufficient. Loteprednol etabonate (LE) is a retrometabolically designed corticosteroid with a low propensity to cause corticosteroid-related adverse effects, such as elevated intraocular pressure (IOP). This review was conducted to provide an assessment of published studies on the use of LE for treatment of inflammation associated with DED. Twelve prospective and 2 retrospective studies evaluating LE ophthalmic suspension $0.5 \%$ and 2 prospective studies evaluating LE ophthalmic gel $0.5 \%$ were identified. LE given as monotherapy or with artificial tears (AT) improved signs of DED, especially among patients with a more pronounced inflammatory component, and also improved DED symptoms compared to baseline and/or control. Treatment with LE before cyclosporine A (CsA) therapy reduced stinging upon CsA initiation and provided more rapid relief of DED signs and symptoms than CsA plus AT alone. In patients with meibomian gland dysfunction, LE alone, or in addition to eyelid scrubs/warm compresses, reduced clinical signs and symptoms, and tear proinflammatory cytokine levels. Overall, LE was safe and well tolerated, with minimal effects on IOP. While larger and longerterm studies are warranted, these data support the use of LE as a safe and effective treatment option for DED.
\end{abstract}

Keywords: loteprednol etabonate, dry eye disease, inflammation, ocular surface, intraocular pressure

\section{Introduction}

D RY EYE DISEASE (DED) or dysfunctional tear syndrome (DTS), clinically referred to as keratoconjunctivitis sicca, is defined by the Tear Film and Ocular Surface Society's Dry Eye Workshop II (TFOS DEWS II) panel as a multifactorial disease of the ocular surface characterized by a loss of homeostasis of the tear film and accompanied by ocular symptoms, such as discomfort and visual disturbance. This condition involves tear film instability and hyperosmolarity, ocular surface inflammation and damage, and neurosensory abnormalities. ${ }^{1}$ The central mechanism underlying the pathophysiology of DED is ocular surface water loss leading to hyperosmolar stress, which can result either from reduced lacrimal secretion (aqueous deficient DED) or excessive evaporation from the exposed tear film (evaporative DED). ${ }^{2}$ For both these types of DED, a myriad of factors may contribute to the initiation and progression of the disease, both physiological and environmental. Especially in later stages of the disease, both lacrimal deficiency and evaporative loss can contribute to hyperosmolarity of the tear film, further exacerbating the condition. ${ }^{2}$ The resulting hyperosmolar stress directly or indirectly may induce inflammation resulting in tissue damage and a loss of epithelial and goblet cells. This further decreases surface wettability leading to local tear instability/early tear film

\footnotetext{
${ }^{1}$ Comprehensive Eyecare of Central Ohio, Westerville, Ohio, USA.

${ }^{2}$ Department of Ophthalmology, Ohio State University, Columbus, Ohio, USA.

${ }^{3}$ The Midwest Center for Sight, Des Plaines, Illinois, USA.

${ }_{5}^{4}$ Chicago Cornea Consultants, Hoffman Estates, Illinois, USA.

${ }^{5}$ Northwest Eye Surgeons, Seattle, Washington, USA.
}

(C) Kenneth Beckman et al., 2020; Published by Mary Ann Liebert, Inc. This Open Access article is distributed under the terms of the Creative Commons Attribution Noncommercial License (http://creativecommons.org/licenses/by-nc/4.0/) which permits any noncommercial use, distribution, and reproduction in any medium, provided the original author(s) and the source are cited. 
breakup and resultant worsening hyperosmolarity via a vicious circle. ${ }^{2}$ Tear hyperosmolarity, loss of lubrication, neurosensory factors, and inflammatory mediators contribute to pain in DED, while tear and ocular surface irregularities cause visual symptoms. ${ }^{2}$

Current etiological classification of DED considers the nonmutually exclusive categories of aqueous-deficient dry eye (ADDE) and evaporative dry eye (EDE), ${ }^{1}$ with ADDE divided into Sjögren's syndrome (SS) dry eye and non-SS dry eye and EDE comprising lid-related, or intrinsic, EDE, and ocular surface-related EDE. ${ }^{2}$ Hybrid subtypes of DED, including components of both ADDE and EDE, have also been described. ${ }^{2}$ According to an expert panel from the Cornea, External Disease, and Refractive Society (referred to as the CEDARS DTS panel), the 4 main subtypes/causes of DTS/DED are aqueous deficiency, blepharitis/meibomian gland dysfunction (MGD; evaporative and nonevaporative), goblet cell/mucin deficiency, and exposure-related DTS. ${ }^{3}$

The global prevalence of symptomatic DED ranges from $5 \%$ to $50 \%$, while studies in which DED was diagnosed primarily based on signs have generally yielded higher estimates and more variable rates of disease. ${ }^{4}$ An analysis of data from the 2013 National Health and Wellness Survey, a cross-sectional, population-based survey of U.S. adults 18 years of age and older, reported a prevalence of diagnosed DED of $6.8 \%$, corresponding to 16.4 million people in $2013^{5}$; an additional $2.5 \%$ of participants (corresponding to $\sim 6$ million people) reported symptoms of DED but had not received a diagnosis. ${ }^{5}$ Similarly, in a large U.S. database, the overall prevalence of DED between 2003 and 2015, based on diagnostic codes and pharmacy claims, was $5.3 \%{ }^{6}$ Both analyses found that the prevalence of DED was higher among women than men and increased with age. ${ }^{5,6}$ Another large U.S. claims database analysis showed that DED represented the sixth most common ocular condition for which patients sought care. ${ }^{7}$ DED can impair vision (ie, difficulty reading, driving at night, performing computer work, and watching television) across all levels of disease severity, although generally greater limitations occur with increasing disease severity. ${ }^{8}$ Accordingly, DED is associated with markedly reduced work productivity and work performance as well as with impairment in activities of daily living outside of work. ${ }^{9}$ DED also has a substantial negative impact on health-related quality of life, with burden increasing with severity of disease. ${ }^{10,11}$

Tear replacement with ocular lubricants is often used in the initial management of DED and has historically been considered a mainstay of treatment. ${ }^{12,13}$ Currently 3 prescription medications are approved in the U.S. to treat DED, 2 containing the active cyclosporine $\mathrm{A}(\mathrm{CsA})^{14,15}$ and 1 containing lifitegrast, ${ }^{16}$ however, these medications can take weeks or even months to reach their full effectiveness and may cause burning and/or irritation, ${ }^{3,14-19}$ which can, in turn, affect adherence and persistence. ${ }^{3,14-22}$ Topical corticosteroids, while not approved by the U.S. Food and Drug Administration (FDA) for treatment of DED, have demonstrated efficacy across a range of ocular inflammatory conditions, including DED, and are often used off label to treat moderate-to-severe DED. ${ }^{12,23}$ By targeting inflammation, topical corticosteroids may help to break the vicious cycle of inflammatory immune responses in DED. ${ }^{12}$ However, the long-term use of ocular corticosteroids is associated with a risk of a number of complications, including ocular hypertension, glaucoma, cataracts, and increased susceptibility to infections. ${ }^{12,23,24}$

Loteprednol etabonate (LE) is an ocular corticosteroid that was retrometabolically synthesized via modification from an inactive metabolite of prednisolone acetate (PA) and has a $17 \beta$-chloromethyl ester at the $\mathrm{C}-20$ position in place of the ketone group found in PA, in addition to a $17 \alpha$-etabonate moiety. ${ }^{25,26}$ These modifications preserve the desired pharmacological effect while enabling rapid metabolism to inactive metabolites to limit excess exposure and thus reduce the potential for adverse reactions. ${ }^{27,28}$ Accordingly, LE has a low risk of clinically significant intraocular pressure (IOP) elevations with both short-term and long-term use and exhibits lower rates of clinically significant IOP elevation compared with other corticosteroids. ${ }^{29}$ The incidence of adverse event (AE) reports such as IOP increase, glaucoma, ocular hypertension, and cataracts in association with the use of LE is also reported to be very low. ${ }^{30}$

LE was initially formulated as an ophthalmic suspension at concentrations of $0.2 \%{ }^{31}$ and $0.5 \% .^{32,33} \mathrm{LE}$ ophthalmic suspension $0.5 \%$ is indicated for the treatment of steroidresponsive inflammatory conditions of the palpebral and bulbar conjunctiva, cornea, and anterior segment of the eye as well as for the treatment of postoperative inflammation following ocular surgery. ${ }^{32}$ LE ophthalmic suspension $0.2 \%$ is indicated for the temporary relief of signs and symptoms of allergic conjunctivitis. ${ }^{31}$ Three additional LE formulations have been approved by the FDA for the treatment of postoperative inflammation and pain following ocular surgery. A nonsettling gel formulation of LE $0.5 \%$ was approved in $2012^{34,35}$ and provides consistent, uniform dosing without the need to shake to resuspend the drug before administration. ${ }^{36,37}$ The above formulations all have a 4-times daily (QID) dosing regimen. ${ }^{31,32,35}$ Most recently, 2 formulations which use proprietary technologies and a reduced drug particle size to enhance ocular penetration ${ }^{38}$ were introduced; a higher dose suspension formulation with a twice daily (BID) dosing regimen, LE suspension $1 \%$, was approved in 2018, ${ }^{39,40}$ and in 2019, LE (submicron) gel $0.38 \%$ was approved with 3 times daily dosing 41,42

Table 1 compares the respective drug concentrations and key excipients of approved suspension and gel formulations of LE. Of note, the vehicle of both LE gel $0.5 \%$ and LE (submicron) gel $0.38 \%$ contains mucoadhesive polymers, which may potentiate longer contact time with the ocular surface, ${ }^{36,38}$ and a demulcent/lubricant, which may improve comfort. The LE gel formulations also contain lower concentrations of the preservative benzalkonium chloride (BAK) compared with LE ophthalmic suspension $0.5 \%$ and $1 \%$ and have a $\mathrm{pH}$ close to that of tears, ${ }^{33,36,43}$ which may be beneficial when treating ocular surface disorders. Pharmacokinetic studies in rabbits demonstrated that LE was present at high concentrations in the cornea and conjunctiva through $24 \mathrm{~h}$ following topical administration of LE $0.5 \%$ suspension, ${ }^{44,45}$ LE gel $0.5 \%,{ }^{46}$ and LE gel $0.38 \%{ }^{43}$ In addition, measurable concentrations of LE were detected in tear fluid through $24 \mathrm{~h}$ after topical administration of LE gel $0.5 \%$ in both rabbits and humans. ${ }^{46}$

The TFOS DEWS II staged management and treatment recommendations include a 4-step process for the management of DED (Table 2). These guidelines suggest that repeated short-term pulse therapy of corticosteroids can be an alternative approach (step 2) for patients with moderate-to- 
Table 1. Comparison of Available Formulations of Loteprednol Etabonate

\begin{tabular}{|c|c|c|c|c|c|c|}
\hline Ingredients & Function & $\begin{array}{c}L E \\
\text { suspension } \\
0.2 \%\end{array}$ & $\begin{array}{c}L E \\
\text { suspension } \\
0.5 \%\end{array}$ & $\begin{array}{c}L E \\
\text { suspension } \\
1 \%{ }^{39, \mathrm{c}}\end{array}$ & $\begin{array}{c}L E \\
\text { (submicron) } \\
\text { gel } 0.38 \%\end{array}$ & $\begin{array}{c}\text { LE gel } \\
0.5 \%\end{array}$ \\
\hline \multicolumn{7}{|l|}{ Active substance } \\
\hline LE & Steroid, anti-inflammatory & $2.0 \mathrm{mg} / \mathrm{mL}$ & $5.0 \mathrm{mg} / \mathrm{mL}$ & $10.0 \mathrm{mg} / \mathrm{mL}$ & $3.8 \mathrm{mg} / \mathrm{g}$ & $5.0 \mathrm{mg} / \mathrm{g}$ \\
\hline \multicolumn{7}{|l|}{ Key excipients ${ }^{32,39}$} \\
\hline Povidone & Suspending and/or & + & + & - & - & - \\
\hline Polycarbophil & viscosity-increasing & - & - & - & + & + \\
\hline Hypromellose & agents & - & - & - & + & - \\
\hline Tyloxapol & Surfactants and/or wetting agents & + & + & - & - & + \\
\hline Poloxamer & & - & - & + & + & - \\
\hline Glycerin & Tonicity agents/humectants & + & + & + & + & + \\
\hline Propylene glycol & & - & - & - & + & + \\
\hline $\begin{array}{l}\text { Edetate disodium } \\
\text { dehydrate }\end{array}$ & Chelant/antimicrobial enhancer & + & + & + & + & + \\
\hline $\begin{array}{l}\text { BAK } \\
\text { pH }\end{array}$ & Antimicrobial preservative & $\begin{array}{l}100 \mathrm{ppm} \\
5.5^{38}\end{array}$ & $\begin{array}{l}100 \mathrm{ppm} \\
5.5^{38}\end{array}$ & $\begin{array}{l}100 \mathrm{ppm} \\
\text { N/A }\end{array}$ & $\begin{array}{l}30 \mathrm{ppm} \\
6.5^{43}\end{array}$ & $\begin{array}{c}30 \mathrm{ppm} \\
6.5^{43}\end{array}$ \\
\hline 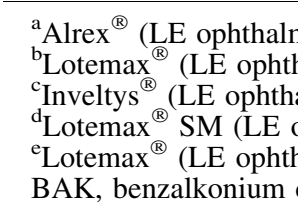 & $\begin{array}{l}\text { nic suspension) } 0.2 \% \text {, Bausch + Lomb. } \\
\text { almic suspension) } 0.5 \% \text {, Bausch + Lomb } \\
\text { almic suspension) } 1 \% \text {, Kala Pharmaceut } \\
\text { phthalmic gel) } 0.38 \% \text {, Bausch + Lomb. } \\
\text { almic gel) } 0.5 \% \text {, Bausch + Lomb. }\end{array}$ & als. & & & & \\
\hline
\end{tabular}

severe DED not controlled with other therapies. ${ }^{12}$ Longterm corticosteroid therapy is recommended as step 4 in staged management of DED. Similarly, the CEDARS DTS Panel concluded that all ophthalmic corticosteroid formulations are suitable for treatment of inflammation associated with tear insufficiency. ${ }^{3}$ Both panels recommend consideration of topical corticosteroids such as LE that pose a lower risk of corticosteroid-related AEs. ${ }^{3,12}$ In this study, we review published clinical studies on the use of LE for the treatment of DED.

\section{Methods}

\section{Search strategy and criteria for inclusion}

A literature search was conducted using BIOSIS Previews from 1993, Medline from 1946, and EMBASE from 1947 through October 2019 (using ProQuest Dialog). Specific search terms were "loteprednol" and "dry eye syndrome" or "dry eye disease" or "keratoconjunctivitis sicca". In addition, PubMed was searched with no time limitation using the following search terms: "loteprednol" or "dry eye" or "sicca" or "meibomian" or "Sjögren's" or "Sjögren". Bibliographies of identified references and review articles were also searched for relevant citations. All articles selected for inclusion reported on use for LE for the treatment of DED in human subjects.

\section{Results}

The literature search identified 16 prospective studies (12 of LE suspension $0.5 \%, 2$ of LE gel $0.5 \%$ ) and 2 retrospective studies of LE suspension $0.5 \% .^{22,47-61}$ Of these, 6 studies evaluated LE monotherapy or in combination with artificial tears (AT), 6 studies evaluated LE in combination with and/or compared to CsA, and 4 evaluated LE for the treatment of MGD. Efficacy and safety findings of each study are summarized in Table 3 and summarized by category below.

\section{LE monotherapy or with AT}

Pflugfelder et al. evaluated LE suspension $0.5 \%$ for 4 weeks versus vehicle, both instilled QID, for the treatment of the inflammatory component of keratoconjunctivitis sicca in patients with delayed tear clearance. ${ }^{47}$ For the primary subjective variable (visual-analog scale [VAS] score for the worst symptom in the worst eye) and the primary objective variable (composite corneal fluorescein staining [CFS] score in the worst eye), changes from baseline to week 4 were significant $(P<0.001)$ for both LE $0.5 \%$ and vehicle, and the difference between LE $0.5 \%$ and vehicle was not statistically significant for either variable. ${ }^{47}$ Compared with vehicle, LE $0.5 \%$ reduced nasal bulbar conjunctival hyperemia at weeks 2 and $4(P<0.05)$ and reduced inferior tarsal conjunctival hyperemia at week $2(P<0.05){ }^{47}$ A subset analysis was performed in patients with at least a moderate inflammatory component (at least 2 of the following criteria: combined CFS score of $\geq 10$ [Cst criterion], conjunctival injection in at least 1 area of $\geq 2$ [Conj criterion], worst symptom score on VAS of $\geq 70$ [Subj criterion], and redness symptom score on VAS of $\geq 70$ [Red criterion]). In this analysis, LE $0.5 \%$ reduced both central CFS ( $\sim 33 \%$ improvement) and nasal bulbar conjunctival hyperemia in patients meeting Subj/Red or Subj/Conj criteria at week 2 (all comparisons, $P<0.05$ versus vehicle). ${ }^{47}$ Reduced nasal bulbar conjunctival hyperemia was also evident in patients meeting the Cst/Conj criteria at 2 weeks. Differences between LE $0.5 \%$ and vehicle did not reach significance by week 4, with the exception of reduced nasal bulbar conjunctival hyperemia and lid margin injection in patients meeting the Subj/Red criteria $(P<0.05$ for both $) .{ }^{47}$ The authors concluded that LE $0.5 \%$ instilled QID may be beneficial in patients who have keratoconjunctivitis sicca with at least a moderate inflammatory component. ${ }^{47}$

Villani et al. assessed the efficacy of LE suspension $0.5 \%$ (QID for 4 weeks) in patients with moderate-to-severe 
Table 2. Staged Management and Treatment Recommendations for Dry Eye Disease (ADAPTED FROM JONES ET AL. ${ }^{\text {I2) }}$

Step 1:

- Education regarding the condition, its management, treatment, and prognosis

- Modification of local environment

- Education regarding potential dietary modifications (including oral essential fatty acid supplementation)

- Identification and potential modification/elimination of offending systemic and topical medications

- Ocular lubricants of various types (if MGD is present, then consider lipid-containing supplements)

- Lid hygiene and warm compresses of various types

Step 2:

If above options are inadequate consider:

- Nonpreserved ocular lubricants to minimize preservative-induced toxicity

- Tea tree oil treatment for Demodex (if present)

- Tear conservation o Punctal occlusion

o Moisture chamber spectacles/goggles

- Overnight treatments (such as ointment or moisture chamber devices)

- In-office, physical heating and expression of the meibomian glands (including device-assisted therapies, such as LipiFlow)

- In-office intense pulsed light therapy for MGD

- Prescription drugs to manage DED ${ }^{\mathrm{a}}$

o Topical antibiotic or antibiotic/steroid combination applied to the lid margins for anterior blepharitis (if present)

o Topical corticosteroid (limited-duration)

o Topical secretagogues

o Topical nonglucocorticoid immunomodulatory drugs (such as cyclosporine)

o Topical LFA-1 antagonist drugs (such as lifitegrast)

o Oral macrolide or tetracycline antibiotics

Step 3:

If above options are inadequate consider:

- Oral secretagogues

- Autologous/allogeneic serum eye drops

- Therapeutic contact lens options

o Soft bandage lenses

o Rigid scleral lenses

Step 4:

If above options are inadequate consider:

- Topical corticosteroid for longer duration

- Amniotic membrane grafts

- Surgical punctal occlusion

- Other surgical approaches (eg, tarsorrhaphy, salivary gland transplantation)

Potential variations within the disease spectrum are acknowledged to exist between patients and the management options listed above are not intended to be exclusive. The severity and etiology of the DED state will dictate the range and number of management options selected from 1 or more steps.

One or more options concurrently within each category can be considered within that step of the DED state. Options within a category are not ranked according to importance and may be equally valid.

It should be noted that the evidence available to support the various management options differs and will inevitably be lower for newer management options. Thus, each treatment option should be considered in accordance with the level of evidence available at the time management is instigated.

${ }^{\mathrm{a}}$ The use of prescription drugs needs to be considered in the context of the individual patient presentation, and the relative level of evidence supporting their use for that specific indication, as this group of agents differs widely in mechanism of action.

DED, dry eye disease; LFA-1, lymphocyte function-associated antigen 1; MGD, meibomian gland dysfunction.

DED. ${ }^{48}$ Ocular Surface Disease Index (OSDI) score, CFS, lissamine green conjunctival staining, dendritic cell density (DCD), and hyperreflective keratocyte density improved from baseline to 4 weeks $(P<0.01$ for all $){ }^{48}$ No significant changes were observed in epithelial and keratocyte cell densities, subbasal nerve length, or nerve tortuosity. Patients who demonstrated a Minimal Clinically Important Difference in OSDI scores based on prespecified thresholds of improvement exhibited a decrease in DCD $(P<0.01)$, whereas those without improvement did not. No differences were observed for the other evaluated signs between patients who responded symptomatically to LE and those who did not. ${ }^{48}$

Jung et al. compared a BID dosing regimen of LE suspension $0.5 \%$ or fluorometholone (FML) suspension $0.1 \%$, both in combination with AT in Korean patients with severe dry eye associated with SS. ${ }^{49}$ In both treatment groups, similar improvements from baseline in tear production (Schirmer test), keratoepitheliopathy, and symptom scores were observed at $6,12,18$, and 24 months $(P<0.05)$ and in tear film breakup time (TBUT) at 12, 18, and 24 months $(P<0.05)$ (Fig. 1). Safety data suggested that LE may have a lower risk of IOP elevation than FML with long-term treatment. 49

In 2 small studies, investigators evaluated the use of low, tapered doses of LE suspension $0.5 \%$ in patients with DED. In the first study, patients received LE suspension $0.5 \%$ or saline, tapered over 8 weeks. Compared to salinetreated controls, patients receiving LE experienced significant 
Table 3. Clinical Trials of Loteprednol Etabonate for the Treatment of Dry Eye Disease

\begin{tabular}{|c|c|c|c|}
\hline Study & Patients & $\begin{array}{c}\text { Study design, treatment, } \\
\text { and duration }\end{array}$ & Key findings \\
\hline \multicolumn{4}{|c|}{ LE monotherapy or with AT } \\
\hline $\begin{array}{c}\text { Pflugfelder } \\
\text { et al. }\end{array}$ & $\begin{array}{l}66 \text { patients } \geq 18 \text { years of age } \\
\text { with keratoconjunctivitis } \\
\text { sicca of } \geq 6 \text { months' } \\
\text { duration and delayed tear } \\
\text { clearance }\end{array}$ & $\begin{array}{l}\text { Multicenter, randomized, } \\
\text { double-masked, vehicle- } \\
\text { controlled trial; patients } \\
\text { received LE suspension } \\
0.5 \%(n=32) \text { or vehicle } \\
(n=34) \text { QID for } 4 \text { weeks }\end{array}$ & $\begin{array}{l}\text { - LE and vehicle both improved worst DED } \\
\text { symptom and CFS compared with } \\
\text { baseline, but differences between groups } \\
\text { were not statistically significant } \\
\text { - LE demonstrated significant }(P<0.05) \\
\text { benefits over vehicle for reducing } \\
\text { conjunctival hyperemia } \\
\text { - In a subset of patients with at least a } \\
\text { moderate inflammatory component, LE } \\
\text { significantly }(P<0.05) \text { improved CFS } \\
\text { staining, nasal bulbar conjunctival } \\
\text { hyperemia, and lid margin injection } \\
\text { versus vehicle at some visits } \\
\text { - No clinically significant IOP elevations } \\
\text { noted } \\
\text { - No significant change in mean IOP } \\
\text { - } \geq 1 \text { treatment-related AE: } 16.7 \% \text { LE } \\
\text { versus } 23.5 \% \text { vehicle (treatment-related } \\
\text { ocular AEs included increased burning, } \\
\text { redness, blurring of vision, foreign body } \\
\text { sensation) } \\
\text { - No treatment-related serious AEs }\end{array}$ \\
\hline $\begin{array}{l}\text { Villani } \\
\text { et al. }\end{array}$ & $\begin{array}{l}50 \text { eyes } / 50 \text { patients with } \\
\text { moderate-to-severe dry eye } \\
\text { symptoms }>6 \text { months }\end{array}$ & $\begin{array}{l}\text { Prospective, open-label, } \\
\text { masked study; all patients } \\
\text { received LE suspension } \\
0.5 \% \text { QID for } 4 \text { weeks }\end{array}$ & $\begin{array}{l}\text { - LE improved signs (fluorescein and } \\
\text { lissamine green staining, DCD, } \\
\text { hyperreflective keratocyte density) and } \\
\text { symptoms (OSDI) compared with } \\
\text { baseline (all } P<0.01 \text { ) } \\
\text { - No reports of AEs }\end{array}$ \\
\hline $\begin{array}{l}\text { Jung } \\
\quad \text { et al. }\end{array}$ & $\begin{array}{l}133 \text { eyes/133 patients with } \\
\text { severe dry eye associated } \\
\text { with SS whose symptoms } \\
\text { were refractory to AT or } \\
\text { topical CsA }\end{array}$ & $\begin{array}{l}\text { Retrospective chart review; } \\
\text { patients received LE } \\
\text { suspension } 0.5 \% \text { BID+AT } \\
6 \text { times per day }(n=66) \text { or } \\
\text { FML } 0.1 \% \text { BID+AT } 6 \\
\text { times per day }(n=67) \text { for } 2 \\
\text { years }\end{array}$ & $\begin{array}{l}\text { - LE+AT and FML+AT groups both } \\
\text { experienced improvement in signs } \\
\text { (Schirmer's scores, keratoepitheliopathy } \\
\text { scores, TBUT) and symptoms over } 2 \\
\text { years of treatment (all } P<0.05) \text {, with no } \\
\text { significant differences between treatment } \\
\text { groups at any time point } \\
\text { - IOP elevations }>2 \text { mmHg were more } \\
\text { common in the FML+AT group than in } \\
\text { the LE+AT group; among patients with } \\
\text { IOP elevations }>2 \text { mmHg at } 2 \text { years, mean } \\
\text { IOP at } 2 \text { years was significantly higher } \\
\text { with FML }(16.50 \text { mmHg versus LE } \\
15.0 \text { mmHg; } P=0.04) \\
\text { - No significant elevation in mean IOP at } \\
\text { any follow-up visit versus baseline } \\
\text { - No significant differences between groups } \\
\text { in mean IOP } \\
\text { - No patients required medication to treat } \\
\text { elevated IOP } \\
\text { - IOP elevations }>2 \text { mmHg versus baseline } \\
\text { occurred in LE group/FML group in } \\
1.5 \% / 3.0 \% \text { of patients at } 6 \text { months, } 1.5 \% \text { I } \\
4.5 \% \text { at } 12 \text { months, } 4.5 \% / 9.0 \% \text { at } 18 \\
\text { months, and } 6.1 \% / 13.4 \% \text { at } 24 \text { months } \\
\text { - Among patients with IOP elevations } \\
>2 \text { mmHg at } 24 \text { months, mean IOP was } \\
\text { significantly higher at } 24 \text { months with } \\
\text { FML ( } 16.5 \text { mmHg) versus LE (15.0; } \\
P=0.04)\end{array}$ \\
\hline
\end{tabular}


Table 3. (Continued)

\begin{tabular}{|c|c|c|c|}
\hline Study & Patients & $\begin{array}{l}\text { Study design, treatment, } \\
\text { and duration }\end{array}$ & Key findings \\
\hline $\begin{array}{l}\text { Barabino } \\
\text { et al. }^{50}\end{array}$ & 20 patients with DED & $\begin{array}{l}\text { Double-masked, randomized } \\
\text { pilot study; patients } \\
\text { received LE suspension } \\
0.5 \%(n=10) \text { or saline } \\
(n=10) \text {, each BID for } 14 \\
\text { days, followed by QD for } \\
15 \text { days and then EOD for } \\
4 \text { weeks }\end{array}$ & $\begin{array}{l}\text { - Compared with vehicle, LE significantly } \\
\text { improved ocular surface inflammation } \\
\text { and symptoms (OSDI questionnaire) at } \\
\text { weeks } 2 \text { and } 8 \\
\text { - No significant differences between groups } \\
\text { for TBUT or corneal staining, although } \\
\text { the LE group demonstrated a consistent } \\
\text { trend for improvement in lissamine green } \\
\text { staining } \\
\text { - No significant increase in IOP in any } \\
\text { treated eyes } \\
\text { - No worsening of BCVA in any treated } \\
\text { eyes }\end{array}$ \\
\hline $\begin{array}{l}\text { Rolando } \\
\text { et al. }\end{array}$ & $\begin{array}{l}36 \text { patients with } \\
\text { keratoconjunctivitis sicca }\end{array}$ & $\begin{array}{l}\text { Prospective randomized } \\
\text { study; patients assigned to } \\
\text { LE suspension BID for } 10 \\
\text { days }(n=12) \text { or LE } \\
\text { suspension } 0.5 \% \text { BID for } 7 \\
\text { days followed by LE QD } \\
\text { for } 15 \text { days and then EOD } \\
\text { for } 3 \text { weeks, followed by } \\
2 \times / \text { week; all patients } \\
\text { received continuous use of } \\
\text { AT TID }\end{array}$ & $\begin{array}{l}\text { - Although signs and symptoms of DED } \\
\text { improved significantly compared with } \\
\text { baseline, the group receiving tapered } \\
\text { doses of LE over a prolonged period } \\
\text { performed better than the group receiving } \\
\text { LE BID for } 10 \text { days }(P<0.001) \\
\text { - No significant increase in IOP in any } \\
\text { treated eyes }\end{array}$ \\
\hline $\begin{array}{l}\text { Aragona } \\
\quad \text { et al. }\end{array}$ & $\begin{array}{l}15 \text { female healthy controls, } 30 \\
\text { female patients with SS, } \\
\text { and } 30 \text { female patients with } \\
\text { MGD }\end{array}$ & $\begin{array}{l}\text { Investigator-masked, } \\
\text { randomized, case-control } \\
\text { study; patients with SS or } \\
\text { MGD received LE } \\
\text { suspension } 0.5 \% \\
\text { QID+saline as needed at } \\
\text { least QID }(n=15) \text { or saline } \\
\text { as needed at least QID } \\
\text { alone for } 15 \text { days }(n=15)\end{array}$ & $\begin{array}{l}\text { - Compared with healthy control subjects, } \\
\text { patients with SS or MGD had elevated } \\
\text { levels of both MMP-9 and TG-2 } \\
\text { expression }(P<0.0001 \text { for all } \\
\text { comparisons) } \\
\text { - In patients with SS or MGD, LE } \\
\text { significantly }(P<0.05) \text { improved signs } \\
\text { (corneal and conjunctival staining, } \\
\text { Schirmer test scores in patients with SS } \\
\text { only, TBUT in patients with MGD only) } \\
\text { and symptoms of DED, whereas saline } \\
\text { alone did not } \\
\text { - In both patient subgroups, LE reduced } \\
\text { MMP-9 and TG-2 levels versus baseline } \\
\text { and versus saline alone ( } P \leq 0.006 \text { all } \\
\text { comparisons) } \\
\text { - IOP findings not reported } \\
\text { - Additional safety results not reported }\end{array}$ \\
\hline \multicolumn{4}{|c|}{ LE in combination with and/or compared to CsA } \\
\hline $\begin{array}{l}\text { Wan } \\
\text { et al. }\end{array}$ & $\begin{array}{l}68 \text { eyes/34 patients aged } 18- \\
60 \text { with grade } 2 \text { or } 3 \text { (based } \\
\text { on the DEWS standard) } \\
\text { xerophthalmia }\end{array}$ & $\begin{array}{l}\text { Prospective, randomized } \\
\text { study; patients received LE } \\
\text { suspension } 0.5 \% \text { BID } \\
\text { ( } n=38 \text { eyes) or CsA } 1 \% \\
\text { BID ( } n=30 \text { eyes) in } \\
\text { addition to carbomer eye } \\
\text { gel ( } 4-6 \text { times/day) }\end{array}$ & $\begin{array}{l}\text { - Signs (CFS, goblet cell density, TBUT) } \\
\text { and symptoms of DED improved versus } \\
\text { baseline in both groups (all } P<0.05) \\
\text { - LE significantly }(P<0.05) \text { improved } \\
\text { symptoms (sum of scores for dryness, } \\
\text { foreign body sensation, burning, } \\
\text { photophobia, and blurred vision, each } \\
\text { rated on a severity scale of } 0-9) \text { versus } \\
\text { CsA at } 2,4 \text {, and } 6 \text { weeks, but not } 8 \text { weeks } \\
\text { - Mean IOP did not differ significantly from } \\
\text { baseline or between treatment groups } \\
\text { - No AEs were reported }\end{array}$ \\
\hline
\end{tabular}

(continued) 
Table 3. (Continued)

\begin{tabular}{|c|c|c|c|}
\hline Study & Patients & $\begin{array}{l}\text { Study design, treatment, } \\
\text { and duration }\end{array}$ & Key findings \\
\hline $\begin{array}{l}\text { Boynton } \\
\text { et al. }\end{array}$ & $\begin{array}{l}150 \text { eyes/75 patients with } \\
\text { DED after HSCT }\end{array}$ & $\begin{array}{l}\text { Single-center randomized } \\
\text { prospective trial; patients } \\
\text { received LE suspension } \\
0.5 \% \text { BID ( } n=76 \text { eyes } / 38 \\
\text { patients) or CsA } 0.05 \% \\
\text { BID ( } n=74 \text { eyes } / 37 \\
\text { patients) from } 1 \text { month } \\
\text { before HSCT to } 12 \text { months } \\
\text { after HSCT }\end{array}$ & $\begin{array}{l}\text { - No significant differences between LE } \\
\text { and CsA groups in DED incidence or } \\
\text { progression } \\
\text { - Among eyes with no DED at enrollment, } \\
\text { the rate of development of DED at } \\
12 \text { months after HSCT was } 79 \% \text { in LE- } \\
\text { treated eyes and } 90 \% \text { in CsA-treated eyes } \\
\text { - At } 12 \text { months, no significant differences } \\
\text { between treatment groups in signs (tear } \\
\text { osmolarity, corneal and conjunctival } \\
\text { staining, Schirmer test score) or } \\
\text { symptoms (OSDI scores) of DED } \\
\text { - Mean change in BCVA did not differ } \\
\text { between treatment groups at } 12 \text { months } \\
\text { - No patient from either group had an IOP } \\
\text { elevation } 10 \text { mmHg at any time point or } \\
\text { discontinued treatment due to IOP } \\
\text { elevation } \\
\text { - No difference between treatments in mean } \\
\text { change in IOP from baseline over } \\
12 \text { months }\end{array}$ \\
\hline $\begin{array}{l}\text { Evans } \\
\quad \text { et al. }\end{array}$ & $\begin{array}{l}102 \text { patients with mild or } \\
\text { moderate DED }\end{array}$ & $\begin{array}{l}\text { Phase } 2, \text { multicenter, } \\
\text { randomized, exploratory } \\
\text { study; patients received LE } \\
\text { gel 0.5\% BID for } 12 \text { weeks } \\
(n=36) \text {, LE gel } 0.5 \% \text { BID } \\
\text { for weeks } 1-4+\text { CsA } 0.05 \% \\
\text { BID for weeks } 3-12 \\
\text { (LE induction therapy; } \\
n=33 \text { ), or CsA } 0.05 \% \text { BID } \\
\text { for } 12 \text { weeks }(n=33)\end{array}$ & $\begin{array}{l}\text { - LE BID for } 12 \text { weeks, LE BID for weeks } \\
\text { 1-4+CsA BID for weeks 3-12 (induction } \\
\text { therapy), and CsA BID for } 12 \text { weeks all } \\
\text { significantly (based on 95\% CIs) reduced } \\
\text { fluorescein staining and symptoms (OSDI, } \\
\text { Comfort Index) of DED over } 12 \text { weeks } \\
\text { and LE and CsA also significantly reduced } \\
\text { lissamine green staining } \\
\text { - No significant differences for LE gel or } \\
\text { LE gel+CsA versus CsA alone at } 12 \\
\text { weeks, however improvement with LE } \\
\text { gel or LE gel+CsA versus CsA was } \\
\text { observed for some outcomes at earlier } \\
\text { time points } \\
\text { - } 2 \text { instances of elevated IOP (>21 mmHg), } \\
\text { both at week 12: } 1 \text { in the LE gel group } \\
\text { and } 1 \text { during CsA treatment in the LE } \\
\text { gel+CsA group } \\
\text { - Few instances of burning, stinging, or } \\
\text { discomfort upon instillation } \\
\text { - Few AEs (all ocular) } \\
\text { - No serious AEs }\end{array}$ \\
\hline $\begin{array}{l}\text { Sheppard } \\
\text { et al. }\end{array}$ & $\begin{array}{l}72 \text { patients with mild-to- } \\
\text { moderate chronic DED }\end{array}$ & $\begin{array}{l}\text { Retrospective analysis; first } \\
\text { cohort of consecutive } \\
\text { patients (LE induction } \\
\text { group) received LE } \\
\text { suspension } 0.5 \% \text { BID for } \\
2-16 \text { months, followed by } \\
\text { concomitant topical CsA } \\
0.05 \% \text { emulsion for } 3-6 \\
\text { months and CsA alone } \\
\text { thereafter ( } n=36 \text { ); second } \\
\text { cohort of consecutive } \\
\text { patients received CsA } \\
\text { alone for at least } 6 \text { months } \\
(n=36)\end{array}$ & $\begin{array}{l}\text { - Compared with CsA alone, significantly } \\
\text { fewer patients in the LE induction group } \\
\text { developed severe stinging }(5.5 \% \text { versus } \\
22 \%, P<0.02) \text { or discontinued treatment } \\
\text { due to severe stinging ( } 2.8 \% \text { versus } 8.3 \% \text {, } \\
P<0.04) \\
\text { - LE induction therapy resulted in } \\
\text { significant improvement in objective } \\
\text { signs of DED at } 3 \text { months (based on a } \\
\text { composite score that included fluorescein } \\
\text { staining, conjunctival redness, and tear } \\
\text { meniscus height; relative risk [95\% CI], } \\
1.1[0.8-1.6] \text {; odds ratio [ } 95 \% \mathrm{CI}], 1.2 \\
[0.5-2.8]) \\
\text { - No significant differences between } \\
\text { treatment groups in rates of improvement } \\
\text { in patient-reported eye comfort } \\
\text { - No clinically significant IOP elevations } \\
\text { (increase from baseline of } \geq 6 \text { mmHg at } 2 \\
\text { consecutive visits) were reported }\end{array}$ \\
\hline
\end{tabular}

(continued) 
Table 3. (Continued)

\begin{tabular}{|c|c|c|c|}
\hline Study & Patients & $\begin{array}{l}\text { Study design, treatment, } \\
\text { and duration }\end{array}$ & Key findings \\
\hline $\begin{array}{l}\text { Sheppard } \\
\text { et al. }\end{array}$ & 118 patients with DED & $\begin{array}{l}\text { Multicenter, randomized, } \\
\text { double-masked study; } \\
\text { patients received LE QID } \\
\text { for } 2 \text { weeks followed by } \\
\text { CsA } 0.05 \% \text { BID+LE } \\
\text { suspension } 0.5 \% \text { BID for } 6 \\
\text { weeks }(n=61) \text { or AT QID } \\
\text { for } 2 \text { weeks, followed by } \\
\text { CsA BID+AT BID for } 6 \\
\text { weeks }(n=57)\end{array}$ & $\begin{array}{l}\text { - Pretreatment with LE resulted in an } \\
\text { earlier onset of efficacy for reducing DED } \\
\text { symptoms (OSDI scores) } \\
\text { - Schirmer test scores improved } \\
\text { significantly }(P<0.05) \text { only in the } \\
\text { LE+CsA group } \\
\text { - Only the LE+CsA group showed } \\
\text { significant bilateral improvements in } \\
\text { central and cumulative staining, and } \\
\text { lissamine green staining decreased to a } \\
\text { greater extent in the LE+CsA group } \\
(P<0.05) \\
\text { - Pretreatment with LE significantly } \\
\text { reduced stinging upon initial instillation } \\
\text { of CsA at } 1 \text { month }(P<0.05) \text {, but not at } 2 \\
\text { months } \\
\text { - No changes were observed in IOP within } \\
\text { either treatment group during the study } \\
\text { - No patients discontinued due to IOP } \\
\text { changes } \\
\text { - Most frequent ocular AEs in either group } \\
\text { were eye pain, conjunctival hyperemia, } \\
\text { IOP increase, reduced visual acuity, and } \\
\text { abnormal sensation in the eye }\end{array}$ \\
\hline $\begin{array}{l}\text { Singla } \\
\quad \text { et al. }\end{array}$ & $\begin{array}{l}140 \text { patients with moderate } \\
\text { DED }\end{array}$ & $\begin{array}{l}\text { Prospective, randomized, } \\
\text { comparative, interventional } \\
\text { study; patients ( } n=70 \text { per } \\
\text { group) received CsA } 0.05 \% \\
\text { BID or LE } 0.5 \% \text { QID for } 2 \\
\text { weeks, tapering to BID } \\
\text { over the following } 6 \text { weeks } \\
\text { plus CsA } 0.05 \% \text { BID. All } \\
\text { patients also received AT. }\end{array}$ & $\begin{array}{l}\text { The LE+CsA group had significantly } \\
\text { greater improvement in OSDI score, } \\
\text { TBUT, fluorescein staining, and lissamine } \\
\text { green staining at } 3 \text { and } 6 \text { months }(P \leq 0.03 \\
\text { for all). } \\
\text { - Schirmer scores were significantly greater } \\
\text { with LE+CsA group versus CsA alone } \\
\text { from } 2 \text { weeks onward ( } P \leq 0.008 \text { for all) } \\
\text { - No significant IOP elevations were } \\
\text { observed in the patients receiving LE }\end{array}$ \\
\hline \multicolumn{4}{|c|}{ LE for the treatment of MGD } \\
\hline Lee et al. ${ }^{58}$ & $\begin{array}{l}70 \text { eyes/70 patients with } \\
\text { moderate or severe MGD }\end{array}$ & $\begin{array}{l}\text { Randomized, controlled, } \\
\text { single-masked trial; } \\
\text { patients received } 2 \text { months } \\
\text { of treatment with LE } \\
\text { suspension } 0.5 \% \text { QID plus } \\
\text { eyelid scrubs/warm } \\
\text { compresses ( } n=34 \text { eyes/34 } \\
\text { patients) or eyelid } \\
\text { scrubs/warm compresses } \\
\text { alone (control group; } n=36 \\
\text { eyes/36 patients) }\end{array}$ & $\begin{array}{l}\text { - At } 2 \text { months, there were significant } \\
\text { decreases in tear levels of IL-6, IL- } 8 \text {, and } \\
\text { IL- } 1 \beta \text { in the LE group and IL- } 6 \text { and IL- } 8 \\
\text { in the control group ( } P<0.05) \\
\text { - The LE group showed significantly lower } \\
\text { tear levels of IL- } 8 \text { than the control of IL- } 8 \\
\text { at } 1 \text { month }(P=0.034) \text { and IL-7 at } 2 \\
\text { months }(P=0.03) \\
\text { - The LE group showed greater } \\
\text { improvement in signs (TBUT, corneal } \\
\text { and conjunctival staining at } 1 \text { month, lid } \\
\text { margin abnormality at } 2 \text { months, and } \\
\text { meibum quality at } 1 \text { and } 2 \text { months; all } \\
P<0.05) \\
\text { - Symptoms (OSDI scores) improved over } \\
\text { time in both treatment groups ( } P<0.001) \text {, } \\
\text { with no significant differences between } \\
\text { groups at } 2 \text { months } \\
\text { - No clinically significant IOP elevations } \\
\text { - A small but statistically significant } \\
\text { increase in mean IOP occurred in the LE } \\
\text { group }(P=0.005), \text { although there was no } \\
\text { significant difference between treatment } \\
\text { groups in mean IOP at any time point } \\
\text { Additional safety data not reported }\end{array}$ \\
\hline
\end{tabular}

(continued) 
TABle 3. (CONTINUED)

\begin{tabular}{|c|c|c|c|}
\hline Study & Patients & $\begin{array}{l}\text { Study design, treatment, } \\
\text { and duration }\end{array}$ & Key findings \\
\hline Ko et al. ${ }^{59}$ & $\begin{array}{l}30 \text { patients with a unilateral } \\
\text { ocular prosthesis for } \\
>1 \text { year and obstructive } \\
\text { MGD in the blind eye }\end{array}$ & $\begin{array}{l}\text { Interventional, prospective } \\
\text { case series; all patients } \\
(N=30) \text { performed eyelid } \\
\text { scrubs/warm compresses } \\
\text { BID and instilled LE } \\
\text { suspension } 0.5 \% \text { QID into } \\
\text { the prosthetic eye for } 2 \\
\text { months }\end{array}$ & $\begin{array}{l}\text { - LE+eyelid scrubs/warm compresses was } \\
\text { associated with significant decreases over } \\
2 \text { months in tear levels of IL-6, interferon- } \\
\gamma, \text { monocyte chemotactic protein-1, IL-8, } \\
\text { tumor necrosis factor- } \alpha \text {, and IL-1 } \beta \\
(P<0.001 \text { for each cytokine) } \\
\text { - At } 2 \text { months, there were significant } \\
\text { improvements in prosthetic eye wearers } \\
\text { in ocular symptoms }(P<0.001) \text {, lid } \\
\text { margin abnormalities }(P<0.001) \text {, } \\
\text { meibomian gland expressibility } \\
\text { (P<0.001), and overall meibography } \\
\text { findings }(P=0.037) \\
\text { - Tear levels of IL- } 6 \text {, interferon- } \gamma \text {, } \\
\text { monocyte chemotactic protein-1, IL- } 8 \text {, } \\
\text { tumor necrosis factor- } \alpha \text {, and IL-1 } \beta \\
\text { decreased significantly after } 2 \text { months } \\
\text { ( } P<0.001 \text { for each cytokine) } \\
\text { - No change in meibography scores of the } \\
\text { upper eyelid } \\
\text { - IOP findings not reported }\end{array}$ \\
\hline $\begin{array}{l}\text { Kheirkhah } \\
\text { et al. }\end{array}$ & $\begin{array}{l}60 \text { patients with MGD-related } \\
\text { DED and } 27 \text { age-matched } \\
\text { controls }\end{array}$ & $\begin{array}{l}\text { Double-masked, randomized } \\
\text { trial; patients with DED } \\
\text { received } 4 \text { weeks of BID } \\
\text { treatment with LE } \\
\text { suspension } 0.5 \%(n=20) \text {, } \\
\text { LE suspension } 0.5 \% / \\
\text { tobramycin } 0.3 \%(n=20) \text {, } \\
\text { or AT }(n=20)\end{array}$ & $\begin{array}{l}\text { - At } 4 \text { weeks, LE-treated patients with low } \\
\text { baseline SNFL showed no improvement } \\
\text { in signs or symptoms of DED, while those } \\
\text { with near-normal SNFL had significant } \\
\text { improvements in SANDE severity } \\
(P=0.04) \text { and corneal fluorescein } \\
(P=0.01) \text { scores } \\
\text { - Patients administered with AT with near- } \\
\text { normal SNFL demonstrated improvement } \\
\text { in OSDI, SANDE frequency and severity } \\
\text { scores, and CFS (all } P \leq 0.04) \text { at } 4 \text { weeks } \\
\text { - SNFL may help explain variations in } \\
\text { response to therapy } \\
\text { - IOP findings and other safety findings not } \\
\text { reported }\end{array}$ \\
\hline $\begin{array}{l}\text { Opitz } \\
\text { et al. }^{61}\end{array}$ & $\begin{array}{l}30 \text { patients with MGD-related } \\
\text { DED }\end{array}$ & $\begin{array}{l}\text { Prospective, multicenter, } \\
\text { open-label study; all } \\
\text { patients received LE gel } \\
0.5 \% \text { BID for } 30 \text { days }\end{array}$ & $\begin{array}{l}\text { - LE treatment was associated with } \\
\text { improvement at day } 30 \text { in signs (TBUT, } \\
\text { corneal staining, conjunctival staining, } \\
\text { MGD signs; all } P \leq 0.006 \text { ) and symptoms } \\
\text { (OSDI and SPEED scores; both } \\
P<0.004 \text { ) of DED } \\
\text { - No significant changes in Schirmer II or } \\
\text { tear osmolarity } \\
\text { - IOP findings and other safety findings not } \\
\text { reported }\end{array}$ \\
\hline
\end{tabular}

AE, adverse event; AT, artificial tears; BCVA, best-corrected visual acuity; BID, twice daily; CFS, corneal fluorescein staining; CI, confidence interval; CsA, cyclosporine A; DCD, dendritic cell density; EOD, every other day; FML, fluorometholone; HSCT, hematopoietic stem cell transplantation; IL, interleukin; IOP, intraocular pressure; MMP-9, matrix metalloproteinase-9; OSDI, Ocular Surface Disease Index; QD, once daily; QID, 4 times per day; SANDE, Symptom Assessment in Dry Eye; SNFL, subbasal nerve fiber length; SPEED, Standard Patient Evaluation of Eye Dryness; SS, Sjögren's syndrome; TG-2, transglutaminase-2; TID, 3 times a day; TBUT, tear film breakup time.

improvements in symptoms and inflammation at 2 and 8 weeks. ${ }^{50}$ In the second study, ${ }^{51}$ patients instilled LE suspension $0.5 \%$ BID for 10 days or LE $0.5 \%$ BID for 7 days, with a 5-week taper to 2 days a week thereafter. All patients also received AT. Both groups showed reductions in signs and symptoms of DED compared with baseline $(P<0.001)$, with patients treated with tapered long-term doses experiencing greater improvements $(P<0.001)$.
Two enzymes involved in the progression of ocular surface damage in DED are matrix metalloproteinase (MMP)-9, an enzyme involved in the breakdown of extracellular matrix during both physiological and pathological processes, and the proapoptotic enzyme transglutaminase (TG)-2., ${ }^{2,52}$ The effects of LE suspension on conjunctival expression of these enzymes and on the signs and symptoms of $\mathrm{DED}^{52}$ were evaluated in patients with mild SS and mild MGD. All 

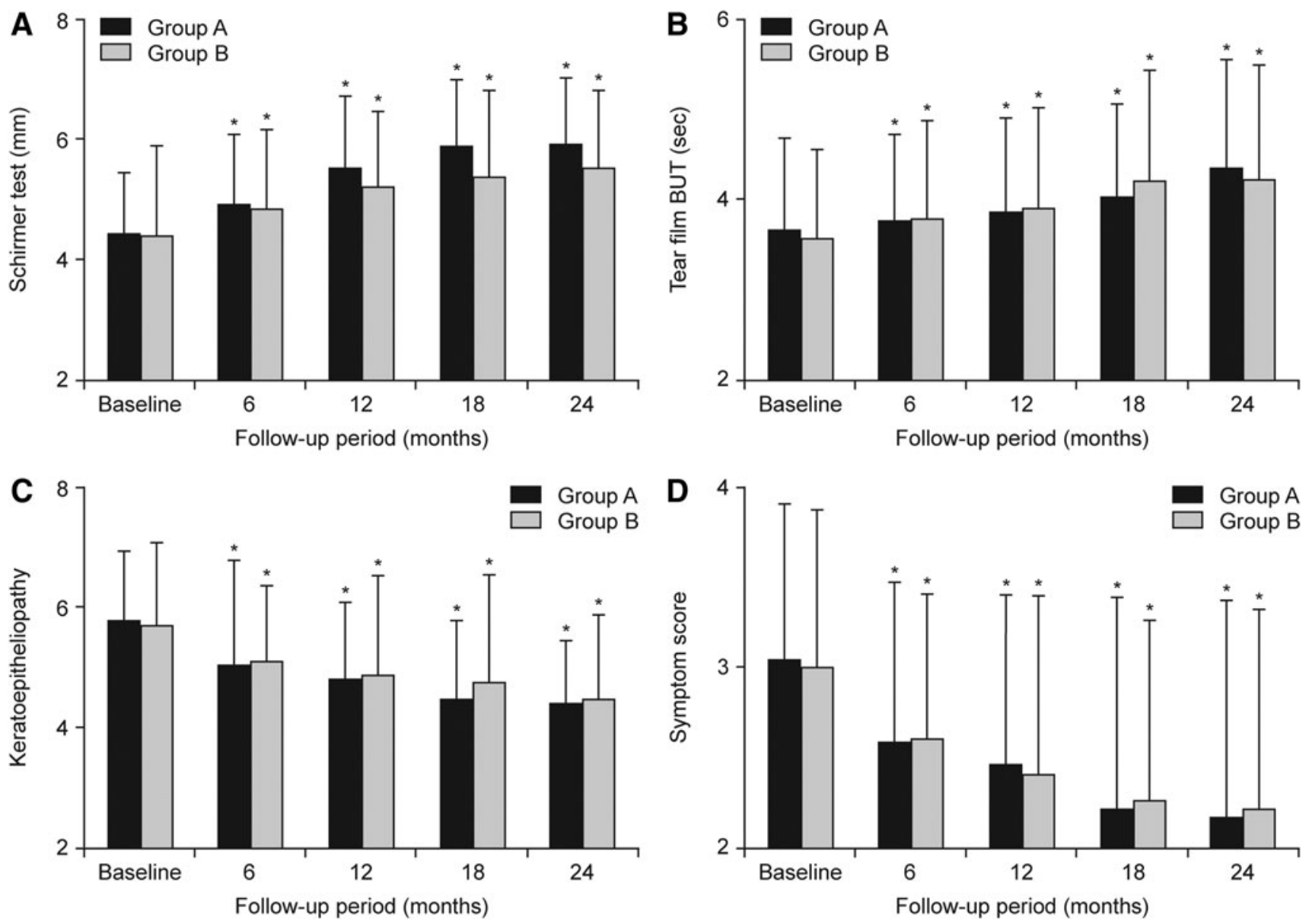

FIG. 1. Changes of Schirmer test (A), TBUT (B), keratoepitheliopathy (C), and symptom score (D) in the LE $0.5 \%$ and fluorometholone $0.1 \%$ groups. ${ }^{49}$ Group A, LE group; Group B, fluorometholone group, $* P<0.05$ versus the baseline. From Jung et al. ${ }^{49}$ Reproduced without modification under the Creative Commons Attribution Noncommercial License (http:// creativecommons.org/licenses/by-nc/3.0) which permits unrestricted noncommercial use, distribution, and reproduction in any medium. LE, loteprednol etabonate; TBUT, tear film breakup time.

patients received saline eye drops as needed and half also received LE $0.5 \%$ QID for 15 days. ${ }^{52}$ Compared with healthy controls, patients with SS or MGD had elevated levels of both MMP-9 and TG-2 $(P<0.0001$ for all). Treatment with LE $0.5 \%$ reduced MMP-9 and TG-2 expression compared with baseline and with saline alone in both subgroups (all $P \leq 0.006$ ). Treatment with LE $0.5 \%$ also reduced symptom scores and corneal and conjunctival staining compared with baseline, while Schirmer I test scores improved only in patients with SS, and TBUT improved only in those with MGD (all $P<0.05)$. None of these measures improved significantly with saline in either patient subgroup. ${ }^{52}$

\section{LE in combination with and/or compared to CsA}

A study in Chinese patients with moderate dry eye $\mathrm{e}^{53}$ evaluated safety and efficacy of 8 weeks of BID treatment with either LE suspension $0.5 \%$ or CsA $1 \%$. All the patients also received $0.2 \%$ carbomer eye gel (4-6 times/day). Both treatment groups experienced reductions in the overall symptom score versus baseline as early as 2 weeks following initiation of treatment $(P<0.01$ for both groups). Greater reductions in overall symptom scores were observed with LE $0.5 \%$ versus CsA $1 \%$ at 2, 4, and 6 weeks (all
$P<0.05)$ but not at week 8 . The authors attributed the difference to less irritation with LE. In both groups, there were similar improvements in CFS at 4, 6, and 8 weeks and goblet cell density at 8 weeks (all $P<0.05$ versus baseline). The TBUT increased in the LE group at 8 weeks and in the CsA group at 6 weeks (both $P<0.01$ versus baseline) with no significant differences in either parameter between groups at 8 weeks. There was no significant improvement in Schirmer's test in either group.

Boynton et al. compared LE suspension $0.5 \%$ to CsA $0.05 \%$ for the prophylaxis and treatment of DED after hematopoietic stem cell transplantation (HSCT). ${ }^{54}$ Both treatments were instilled BID for 1 month before HSCT and 12 months following HSCT, with no differences between treatment groups in DED incidence or progression over the course of the study. Although the LE group demonstrated a significantly $(P=0.004)$ smaller increase in CFS and conjunctival lissamine green staining at 3 months and a significantly greater decrease in Schirmer test score at 9 months $(P=0.01)$, there was no significant difference between groups at 12 months post-HSCT in the average increase in corneal and conjunctival staining from baseline, TBUT, tear osmolarity, change in Schirmer score, best corrected VA, or OSDI. 
The safety and efficacy of LE gel $0.5 \%$ alone and as induction therapy to CsA $0.05 \%$ compared to CsA $0.05 \%$ alone were evaluated in patients with mild-to-moderate DED. ${ }^{55}$ Patients were treated with LE gel $0.5 \%$ BID for 12 weeks, LE gel BID for weeks 1-4, and then CsA $0.05 \%$ BID for weeks 3-12, or CsA BID for weeks 1-12. All 3 treatment regimens reduced signs (CFS staining and TBUT) and symptoms (OSDI and Comfort Index) of DED from baseline to week 12 based on $95 \%$ confidence intervals. At week 2, greater improvement over baseline was observed with LE gel+CsA versus CsA alone for total OSDI $(P=0.022)$ and with both LE gel alone and LE gel+CsA versus CsA alone for OSDI visual function domain questions 6-9 $(P \leq 0.041)$. Compared with CsA alone, LE gel alone produced greater improvement from baseline to week 4 in hyperemia (by keratography) and TBUT $(P \leq 0.04)$. However, at week 12 , no significant differences between LE gel alone or LE gel+CsA compared to CsA alone were noted on any signs or symptoms of DED.

Three studies evaluated LE suspension $0.5 \%$ in combination with CsA for the treatment of DED. ${ }^{22,56,57}$ In the first study, signs, symptoms, and tolerability were compared in patients with mild-to-moderate DED treated with either LE $0.5 \%$ BID for 2 to 16 months before initiation of concomitant CsA therapy or CsA alone. ${ }^{56}$ Fewer of the patients who received LE induction therapy developed severe stinging $(P<0.02)$ or discontinued treatment due to severe stinging compared to patients treated with CsA alone $(P<0.04)$. At 3 months, LE pretreatment was associated with significant improvement in objective signs of DED.

The second study compared induction therapy with LE suspension $0.5 \%$ QID followed by CsA/LE, both BID, to
AT QID followed by CsA/AT BID in patients with mild-tomoderate DED. The LE or AT was instilled alone for 2 weeks followed by an additional 6 weeks in combination with CsA. ${ }^{22}$ While symptoms significantly improved compared to baseline in both treatment groups, the LE group experienced earlier onset of improvement (Fig. 2). Schirmer's test scores improved $(P<0.05)$ in the LE group but not the AT group. Global self-assessment scores, CFS, and required AT use improved from baseline in both groups (all $P<0.05$ ), with no significant differences between groups, although only the LE group exhibited significant improvements in central, inferior, and cumulative CFS. Lissamine green staining decreased in both groups, but LE was more effective in decreasing lissamine green staining. In terms of tolerability, LE $0.5 \%$ reduced stinging associated with CsA at 1 month $(P<0.05)$, but not at 2 months. There were no significant differences between treatment groups for patient's ratings of overall burning, redness, blurred vision, or improvement in eye comfort at 1 and 2 months.

The efficacy of CsA alone versus CsA plus LE suspension $0.5 \%$ were further evaluated in a study in Indian patients with moderate DED. ${ }^{57}$ Patients received CsA BID for 3 months with or without LE suspension $0.5 \%$, QID for 2 weeks, tapered to BID over the following 6 weeks. All patients also received AT, and signs and symptoms of DED were evaluated at 2 and 6 weeks and at 3 and 6 months. There was a greater improvement in OSDI score, TBUT, CFS, and conjunctival lissamine green staining with $\mathrm{LE}+\mathrm{CsA}$ versus CsA alone at 3 and 6 months ( $P \leq 0.03$ for all). Schirmer scores were greater in the LE+CsA group versus the CsA alone group from 2 weeks onward $(P \leq 0.008$ for all).

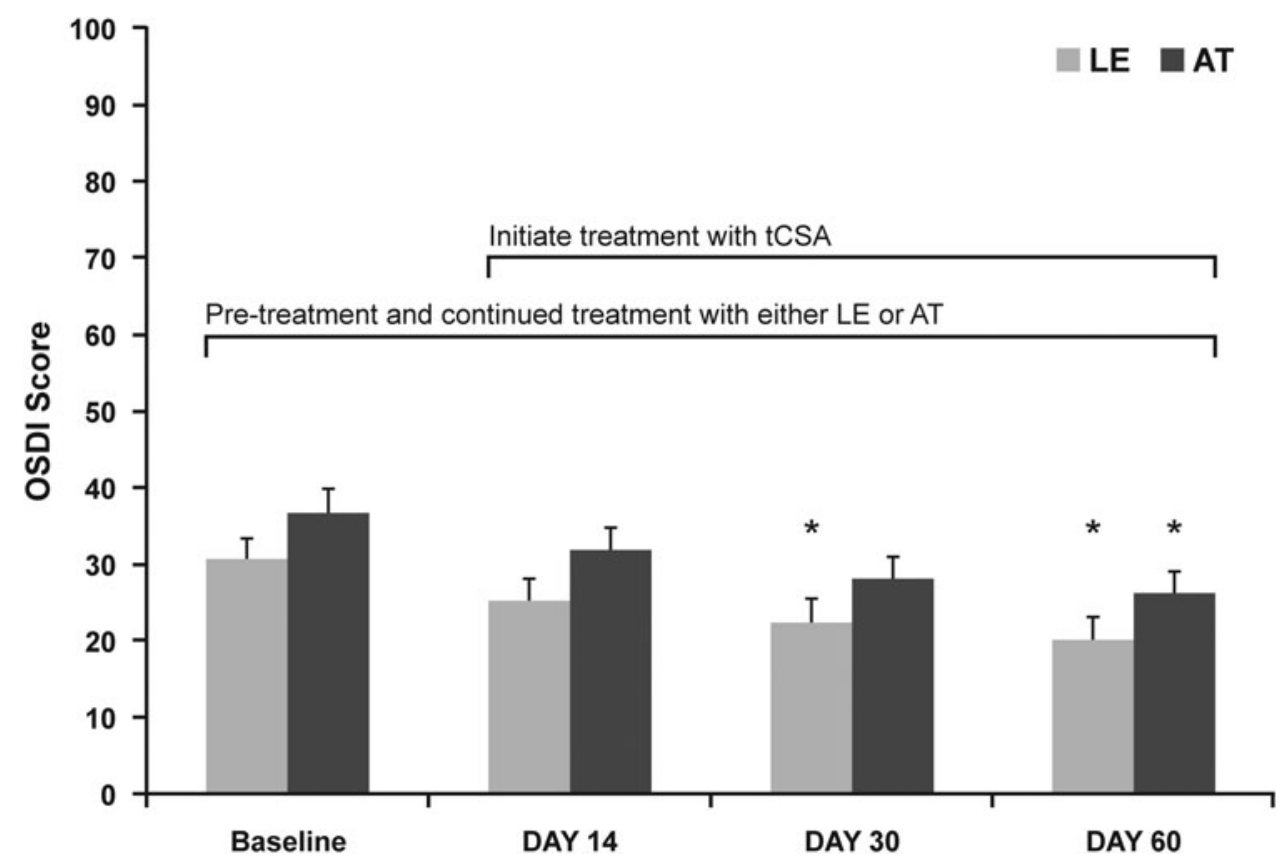

FIG. 2. Mean \pm SEM OSDI scores for $\mathrm{LE}+\mathrm{tCsA}-(n=57)$ and $\mathrm{AT}+\mathrm{tCsA}-(n=55)$-treated patients at baseline and at each of the study visits. ${ }^{22}$ OSDI scores for LE+tCSA- and AT+tCsA-treated patients at baseline and at each day of the study. * Statistically significant versus baseline, $P<0.05$.

From Sheppard et al. ${ }^{22}$ Reproduced with permission from Wolters Kluwer Health. The Creative Commons license does not apply to this content. Use of the material in any format is prohibited without written permission from the publisher, Wolters Kluwer Health, Inc., Please contact permissions@lww.com for further information.

AT, artificial tears; OSDI, Ocular Surface Disease Index; SEM, standard error of the mean; tCsA, topical cyclosporine A. 


\section{$L E$ for the treatment of $M G D$}

A study investigated the effect of LE suspension $0.5 \%$ on tear proinflammatory cytokines and clinical outcomes in patients with moderate or severe MGD. ${ }^{58}$ Patients received LE $0.5 \%$ QID or no corticosteroid for 2 months; all patients also administered eyelid scrubs/warm compresses. At 1 month, LE treatment decreased tear levels of the cytokines interleukin (IL) $-6,-8$, and $-1 \beta$ (all $P \leq 0.03$ ), while there was no effect in the control group; IL-8 levels were also lower in the LE group compared to control $(P=0.034)$. Mean tear levels of IL-6 and IL-8 decreased over 2 months in both groups $(P<0.05)$, while IL-1 $\beta$ decreased in the LE group only $(P<0.05)$; at 2 months, mean levels of IL-7 were lower in the LE group than the control group $(P=0.03)$. Mean TBUT increased over time in both treatment groups, with a larger change in TBUT from baseline to month 1 in the LE group $(P=0.012$ versus control). With the exception of corneal staining in the control group, all staining scores improved over time $(P<0.001)$, with greater improvements in the LE group compared to control at 1 and 2 months (CFS, $P=0.009$ and 0.018 , respectively; conjunctival fluorescein staining, $P=0.007$ and $P<0.001$, respectively; DEWS staining score, $P=0.001$ and $P<0.001$, respectively; Oxford staining score, $P=0.001) .{ }^{58}$ Both groups demonstrated improvement in lid margin abnormality and meibum quality $(P<0.001)$, although the LE group had greater improvement in lid margin abnormality at 2 months and meibum quality at 1 and 2 months compared to baseline $(P \leq 0.02) .{ }^{58}$ Mean OSDI in both groups showed similar improvement over time $(P<0.001)$. Compared with control, the LE group experienced greater improvement in expressibility, ocular irritation score, and MGD stage (all $P<0.05) .{ }^{58}$

The effect of LE suspension $0.5 \%$ on clinical outcomes and tear cytokine levels in patients diagnosed with obstructive MGD in their blind eye wearing a unilateral ocular prosthesis was evaluated in a case series. ${ }^{59}$ Patients instilled LE $0.5 \%$ QID and performed eyelid scrubs with warm compresses BID in their prosthetic eye for 2 months. Tear levels of all cytokines (IL-6, interferon- $\gamma$, monocyte chemotactic protein-1, IL-8, tumor necrosis factor- $\alpha$, and IL-1 $\beta$ ) decreased after 2 months $(P<0.001$ for each). Improvements were observed for lid margin abnormality score, meibomian gland expression, meibography scores of the lower eyelid, and ocular symptom scores $(P \leq 0.037$ for all), although meibography scores of the upper eyelid were unchanged.

Kheirkhah et al. evaluated the effect of LE suspension $0.5 \%$, LE suspension $0.5 \%$ /tobramycin $0.3 \%$, or AT instilled BID bilaterally for 4 weeks in patients with MGD-related DED with low or near-normal baseline corneal subbasal nerve fiber length (SNFL). ${ }^{60}$ Among LE-treated patients, there was no improvement in signs or symptoms of DED in patients with low SNFL, but patients with near-normal SNFL exhibited improvements in Symptom Assessment in Dry Eye (SANDE) severity $(P=0.04)$ and CFS $(P=0.01)$. None of the assessed signs and symptoms of DED improved in the LE/tobramycin groups. In the AT group, improvement at week 4 was only observed for the Schirmer's test $(P=0.04)$ in patients with low SNFL, whereas patients with nearnormal SNFL demonstrated improvement in OSDI, SANDE frequency and severity scores, and CFS (all $P \leq 0.04$ ). Mean SNFL did not change after 4 weeks in the AT group, but increased in the LE and LE/tobramycin groups $(P=0.04$ for both). The authors concluded that significant improvement in symptoms and CFS were generally evident only in patients with near-normal SNFL and suggested that SNFL may help explain variations in response to therapy. In addition, the authors suggested that the LE and LE/tobramycin regimens (BID) may have been inadequate.

The effect of LE gel $0.5 \%$ in patients with MGD was investigated in patients treated with LE gel BID bilaterally for 30 days. $^{61}$ After 30 days, TBUT increased by $44.3 \%$ $(P=0.005)$, while corneal staining, conjunctival staining, and MGD signs decreased (by 52\%, 47.5\%, and 31.9\%, respectively; all $P \leq 0.006)$. Mean OSDI and Standard Patient Evaluation of Eye Dryness scores improved by $32.8 \%$ and $28.5 \%$, respectively (both $P<0.004$ ). Schirmer score and tear osmolarity remained unchanged throughout the study.

\section{Discussion}

Ocular surface inflammation and, in some conditions, secretory components of the lacrimal system, are believed to play a central role in the pathogenesis of DED, and inflammation is universal across all subtypes of DED. ${ }^{3}$ Accordingly, topical corticosteroids are often used to treat the inflammation associated with moderate-to-severe DED. ${ }^{12,23}$ LE is an effective ophthalmic corticosteroid with a reduced risk of corticosteroid-related AEs, such as increased IOP and cataract formation. ${ }^{29}$ While LE has been shown to penetrate efficiently into the aqueous humor following topical ocular instillation of either the suspension or gel formulations, the highest concentrations of LE are consistently achieved on the ocular surface (cornea and conjunctiva). ${ }^{43-46}$

As attested herein, multiple studies have evaluated LE suspension and gel formulations for the treatment of DED stemming from various causes and have also investigated its efficacy as induction therapy in reducing stinging associated with topical CsA in DED. In the 14 reviewed LE suspension $0.5 \%$ studies, dosing regimens were BID (5 studies), ${ }^{49,53,54,56,60}$ QID (6 studies), ${ }^{47,48,52,57-59}$ QID (induction therapy for CsA) followed by BID (in conjunction with CsA; 1 study), ${ }^{22}$ or tapered from BID to every other day ( 2 studies $)^{50,51}$ and ranged from 15 days $^{52}$ to 2 years. ${ }^{49}$ In the 2 studies evaluating LE gel $0.5 \%$, the drug was instilled BID, with treatment duration of 30 days in one study and 12 weeks in the other study. ${ }^{55}$

Results from the 6 studies that evaluated LE suspension $0.5 \%$ monotherapy or LE suspension in addition to AT indicate that LE improves signs of DED and is safe and well tolerated, without clinically significant IOP elevations. ${ }^{47-52}$ Treatment with LE suspension $0.5 \%$ improved DED symptoms from baseline in all studies. ${ }^{47-52}$ In addition, in the 2 studies that compared LE with vehicle/saline, LE showed improvement, although in 1 study this was in a subset of patients with higher levels of inflammation. ${ }^{4,50}$ Therefore, the effect of LE suspension $0.5 \%$ may be greater in patients with a more pronounced inflammatory component of DED. ${ }^{47}$ Furthermore, LE reduced conjunctival levels of 2 enzymes linked to inflammation (MMP-9) and apoptosis (TG-2) in patients with SS or MGD, suggesting that LE may target multiple pathological mechanisms in DED. ${ }^{52}$ When instilled BID in combination with AT in patients with SS over 2 years, LE suspension $0.5 \%$ demonstrated comparable efficacy to FML, but was potentially associated with 
a lower risk of IOP. ${ }^{49}$ Results of 2 small studies that evaluated the efficacy and safety of low, tapered doses of LE suspension $0.5 \%$ are promising, and this approach warrants further study. ${ }^{50,51}$

Results of 3 studies suggest that pretreatment with LE suspension $0.5 \%$ may reduce stinging upon initiation of CsA therapy. ${ }^{22,56,57}$ As well, results of 2 prospective studies suggest that induction therapy with LE suspension $0.5 \%$ before CsA treatment may provide more rapid or greater relief of DED signs and symptoms than CsA and AT. ${ }^{22,57}$ Studies comparing LE suspension $0.5 \%$ with CsA support the safety of LE $0.5 \%$ and suggest that LE $0.5 \%$ may be as effective as CsA for treating DED as well as DED following HSCT. ${ }^{53,54}$ One study evaluating LE gel $0.5 \%$ BID alone or as induction therapy to CsA versus CsA alone for inflammation associated with DED found that all 3 treatment regimens reduced signs and symptoms of DED over 12 weeks of treatment. ${ }^{55}$ Although early advantages were noted for LE gel $0.5 \%$ alone or LE gel $0.5 \%$ plus CsA versus CsA alone on some outcomes, there were no significant differences between treatment groups at 12 weeks. All treatments appeared safe and well tolerated. Results of this study support further investigation of LE gel $0.5 \%$ for the treatment of DED, alone or in combination with CsA.

Regarding MGD, findings of 2 studies suggest that LE suspension $0.5 \%$ QID and eyelid scrubs with warm compresses are beneficial in MGD, including in prosthetic eye wearers. ${ }^{58,59}$ Furthermore, treatment with LE suspension $0.5 \%$ was associated with decreases in levels of tear cytokines, likely related to pharmacological efficacy. ${ }^{59}$ Results of a single open-label study of LE gel $0.5 \%$ BID also support the efficacy of LE for improving the signs and symptoms of dry eye associated with MGD. ${ }^{61}$

Limitations of studies of LE in DED to date include the challenges of DED studies with any treatment, such as the heterogeneity of the condition, the lack of correlation between signs and symptoms, confounding variables (eg, demographics, geographic/environmental factors, ocular or systemic diseases, concomitant medications) that may differentially affect treatment groups, and the difficulty in determining whether observed improvement represents a true treatment effect. ${ }^{62,63}$ Spontaneous improvement/regression to the mean and nontreatment-related improvements associated with participating in a clinical study ("placebo effects") may contribute to perceived improvement, especially in subjective symptoms. ${ }^{62,63}$ Indeed, differentiating between treatment effects and a placebo effect in vehicle-controlled studies is complicated by high placebo response rates in clinical studies of DED and by the potentially therapeutic effects of the vehicle (often essentially an AT) itself. ${ }^{62,63}$ These limitations may make it especially difficult to observe a benefit of a study medication over vehicle in DED studies and may explain the lack of differentiation between LE and vehicle for some of the outcomes in several studies. Finally, while a number of the studies used these measures or components of them, there is also a need to more consistently evaluate the symptoms of DED with validated instruments, such as the OSDI and the DEQ-5. ${ }^{64}$

It should be noted that most of the studies to date evaluated the safety and efficacy of LE suspension $0.5 \%$. However, suspension formulations may be less convenient and possibly less comfortable to instill than gel formula- tions, which do not require shaking, have a lower concentration of BAK, and have a more physiological $\mathrm{pH}^{33,36,38} \mathrm{In}$ addition to preventing settling, the polycarbophil polymer in current LE gel formulations also prolongs ocular surface retention and contains demulcent/lubricants, which may improve comfort. ${ }^{33,36,38}$ The reduction in BAK from $0.01 \%$ in the suspension formulation to $0.003 \%$ in the gel formulations $^{36}$ is important given concerns with use of this preservative in DED patients, especially for those who may be on multiple BAK-containing medications long-term. ${ }^{12,65}$ While LE is also available formulated in a BAK-free ointment, there are no studies to date which have evaluated the ointment for DED. Therefore, larger studies of longer duration are warranted to further assess the safety and sustained efficacy of the newer gel/ointment formulations of LE in DED. In addition, a low-dose suspension formulation of LE (KPI-121 0.25\%; Kala Pharmaceuticals, Waltham, MA) with QID dosing is currently under development/evaluation for temporary relief of the signs and symptoms of DED. ${ }^{66}$

In conclusion, the available studies suggest that LE is a safe and effective treatment for DED, with low risk of elevated IOP or cataract formation. Larger and longer-term controlled studies, particularly with the newer gel formulations, are warranted to further explore the therapeutic value of LE for this condition.

\section{Acknowledgment}

Writing and editorial support was provided by Churchill Communications (Maplewood, NJ).

\section{Author Disclosure Statement}

K.B. is a consultant for Alcon, Allergan, Bausch + Lomb, a division of Bausch Health US, LLC, Eyevance Pharmaceuticals, Kala Pharmaceuticals, Novartis, and Sun Pharmaceutical Industries Ltd. J.K. is a consultant for Allergan, EyePoint Pharmaceuticals, Inc., Novartis, and Ocular Science; he served on an ad board with Eyevance Pharmaceuticals, Kala Pharmaceuticals, and Ocular Therapeutix. P.M. is a consultant for Alcon, Allergan, Bausch + Lomb, a division of Bausch Health US, LLC, Bio-Tissue, Inc., Dompé, Eyevance Pharmaceuticals, Kala Pharmaceuticals, Novaliq, Novartis, and Sun Pharmaceutical Industries Ltd. A.R. is a consultant for Alcon, Allergan, Bausch +Lomb, a division of Bausch Health US, LLC, Kala Pharmaceuticals, Novartis, and Sun Pharmaceutical Industries Ltd.

\section{Funding Information}

Funded by Bausch Health US, LLC.

\section{References}

1. Craig, J.P., Nichols, K.K., Akpek, E.K., et al. TFOS DEWS II definition and classification report. Ocul. Surf. 15:276283, 2017.

2. Bron, A.J., de Paiva, C.S., Chauhan, S.K., et al. TFOS DEWS II pathophysiology report. Ocul. Surf. 15:438-510, 2017.

3. Milner, M.S., Beckman, K.A., Luchs, J.I., et al. Dysfunctional tear syndrome: dry eye disease and associated tear film disorders-new strategies for diagnosis and treatment. Curr. Opin. Ophthalmol. 27(Suppl 1):3-47, 2017. 
4. Stapleton, F., Alves, M., Bunya, V.Y., et al. TFOS DEWS II epidemiology report. Ocul. Surf. 15:334-365, 2017.

5. Farrand, K.F., Fridman, M., Stillman, I.Ö., and Schaumberg, D.A. Prevalence of diagnosed dry eye disease in the United States among adults aged 18 years and older. Am. J. Ophthalmol. 182:90-98, 2017.

6. Dana, R., Bradley, J.L., Guerin, A., et al. Estimated prevalence and incidence of dry eye disease based on coding analysis of a large, all-age United States health care system. Am. J. Ophthalmol. 202:47-54, 2019.

7. Bradley, J.L., Özer Stillman, I., Pivneva, I., Guerin, A., Evans, A.M., and Dana, R. Dry eye disease ranking among common reasons for seeking eye care in a large US claims database. Clin. Ophthalmol. 13:225-232, 2019.

8. Barber, L., Khodai, O., Croley, T., et al. Dry eye symptoms and impact on vision-related function across International Task Force guidelines severity levels in the United States. BMC Ophthalmol. 18:260, 2018.

9. Nichols, K.K., Bacharach, J., Holland, E., et al. Impact of dry eye disease on work productivity, and patients' satisfaction with over-the-counter dry eye treatments. Invest. Ophthalmol. Vis. Sci. 57:2975-2982, 2016.

10. Uchino, M., and Schaumberg, D.A. Dry eye disease: impact on quality of life and vision. Curr. Ophthalmol. Rep. 1:5157, 2013.

11. McDonald, M., Patel, D.A., Keith, M.S., and Snedecor, S.J. Economic and humanistic burden of dry eye disease in Europe, North America, and Asia: a systematic literature review. Ocul. Surf. 14:144-167, 2016.

12. Jones, L., Downie, L.E., Korb, D., et al. TFOS DEWS II management and therapy report. Ocul. Surf. 15:575-628, 2017.

13. Holland, E.J., Darvish, M., Nichols, K.K., Jones, L., and Karpecki, P.M. Efficacy of topical ophthalmic drugs in the treatment of dry eye disease: a systematic literature review. Ocul. Surf. 17:412-423, 2019.

14. Restasis ${ }^{\circledR}$ [package insert]. Irvine, CA: Allergan; 2019.

15. Cequa $^{\mathrm{TM}}$ [package insert]. Cranbury, NJ: Sun Pharmaceutical Industries, Inc.; 2018.

16. Xiidra ${ }^{\circledR}$ [package insert]. Lexington, MA: Shire US, Inc.; 2017.

17. Sheppard, J.D., Torkildsen, G.L., Lonsdale, J.D., et al. Lifitegrast ophthalmic solution $5.0 \%$ for treatment of dry eye disease: results of the OPUS-1 phase 3 study. Ophthalmology. 121:475-483, 2014.

18. Tauber, J., Karpecki, P., Latkany, R., et al. Lifitegrast ophthalmic solution $5.0 \%$ versus placebo for treatment of dry eye disease: results of the randomized phase III OPUS2 study. Ophthalmology. 122:2423-2431, 2015.

19. Holland, E.J., Luchs, J., Karpecki, P.M., et al. Lifitegrast for the treatment of dry eye disease: results of a phase III, randomized, double-masked, placebo-controlled trial (OPUS-3). Ophthalmology. 124:53-60, 2017.

20. Perry, H.D., and Donnenfeld, E.D. Topical 0.05\% cyclosporin in the treatment of dry eye. Expert Opin. Pharmacother. 5:2099-2107, 2004.

21. Mah, F., Milner, M., Yiu, S., Donnenfeld, E., Conway, T.M., and Hollander, D.A. PERSIST: Physician's Evaluation of Restasis $\left({ }^{\circledR}\right)$ Satisfaction in Second Trial of topical cyclosporine ophthalmic emulsion $0.05 \%$ for dry eye: a retrospective review. Clin. Ophthalmol. 6:1971-1976, 2012.

22. Sheppard, J.D., Donnenfeld, E.D., Holland, E.J., et al. Effect of loteprednol etabonate $0.5 \%$ on initiation of dry eye treatment with topical cyclosporine $0.05 \%$. Eye Contact Lens. 40:289-296, 2014.
23. Sy, A., O'Brien, K.S., Liu, M.P., et al. Expert opinion in the management of aqueous deficient dry eye disease (DED). BMC Ophthalmol. 15:133, 2015.

24. McGhee, C.N., Dean, S., and Danesh-Meyer, H. Locally administered ocular corticosteroids: benefits and risks. Drug Saf. 25:33-55, 2002.

25. Druzgala, P., Hochhaus, G., and Bodor, N. Soft drugs-10. Blanching activity and receptor binding affinity of a new type of glucocorticoid: loteprednol etabonate. J. Steroid Biochem. Mol. Biol. 38:149-154, 1991.

26. Bodor, N., Loftsson, T., and Wu, W.M. Metabolism, distribution, and transdermal permeation of a soft corticosteroid, loteprednol etabonate. Pharm. Res. 9:1275-1278, 1992.

27. Bodor, N. Designing safer drugs based on the soft drug approach. Trends Pharmacol. Sci. 3:53-56, 1982.

28. Bodor, N. Recent advances in retrometabolic design approaches. J. Control Release. 62:209-222, 1999.

29. Sheppard, J.D., Comstock, T.L., and Cavet, M.E. Impact of the topical ophthalmic corticosteroid loteprednol etabonate on intraocular pressure. Adv. Ther. 33:532-552, 2016.

30. Cavet, M.E., Sanfilippo, C.M., and DeCory, H.H. Assessment of ophthalmic steroid class adverse event reports for loteprednol etabonate. Invest. Ophthalmol. Vis. Sci. 58: 1082, 2017.

31. Alrex ${ }^{\circledR}$ [package insert]. Bridgewater, NJ: Bausch + Lomb; 2019.

32. Lotemax ${ }^{\circledR}$ [package insert]. Bridgewater, NJ; Bausch + Lomb; 2016.

33. Comstock, T.L., and Sheppard, J.D. Loteprednol etabonate for inflammatory conditions of the anterior segment of the eye: twenty years of clinical experience with a retrometabolically designed corticosteroid. Expert Opin. Pharmacother. 19:337-353, 2018.

34. United States Food and Drug Administration. Drug approval package. 2012. Available at: https://www.accessdata .fda.gov/drugsatfda_docs/nda/2012/202872_lotemax_toc .cfm Accessed August 13, 2019.

35. Lotemax ${ }^{\circledR}$ gel [package insert]. Bridgewater, NJ: Bausch + Lomb; 2018.

36. Coffey, M.J., DeCory, H.H., and Lane, S.S. Development of a non-settling gel formulation of $0.5 \%$ loteprednol etabonate for anti-inflammatory use as an ophthalmic drop. Clin. Ophthalmol. 7:299-312, 2013.

37. Phillips, E., Coffey, M.J., and Shawer, M. Viscoelastic and dissolution characterization of submicron loteprednol etabonate ophthalmic gel, $0.38 \%$. Invest. Ophthalmol. Vis. Sci. 56:1525, 2015.

38. Salinger, C.L., Gaynes, B.I., and Rajpal, R.K. Innovations in topical ocular corticosteroid therapy for the management of postoperative ocular inflammation and pain. Am. J. Manag. Care. 25(12 Suppl):S215-S226, 2019.

39. Inveltys ${ }^{\circledR}$ [package insert]. Waltham, MA: Kala Pharmaceuticals; 2020.

40. Kala Pharmaceuticals. Press release. Kala Pharmaceuticals announces FDA approval of INVELTYS ${ }^{\mathrm{TM}}$ for the treatment of post-operative inflammation and pain following ocular surgery. August 23, 2018. Available at: http:// investors.kalarx.com/node/7301/pdf Accessed September 9, 2019.

41. Lotemax ${ }^{\circledR}$ SM [package insert]. Bridgewater, NJ: Bausch + Lomb; 2019.

42. Bausch + Lomb. Press release. Bausch + Lomb announces FDA approval of Lotemax ${ }^{\circledR}$ SM (loteprednol etabonate ophthalmic gel) $0.38 \%$ for the treatment of postoperative inflammation and pain following ocular surgery. Designed 
with SM technology for efficient penetration at a low preservative (BAK) level. Available at: https://www.bausch .com/our-company/recent-news/artmid/11336/articleid/508/ 2252019-monday Accessed August 13, 2019.

43. Cavet, M.E., Glogowski, S., Lowe, E.R., and Phillips, E. Rheological properties, dissolution kinetics, and ocular pharmacokinetics of loteprednol etabonate (submicron) ophthalmic gel 0.38. J. Ocul. Pharmacol. Ther. 35:291300, 2019.

44. Druzgala, P., Wu, W.M., and Bodor, N. Ocular absorption and distribution of loteprednol etabonate, a soft steroid, in rabbit eyes. Curr. Eye Res. 10:933-937, 1991.

45. Glogowski, S., and Proksch, J.W. Ocular pharmacokinetics of loteprednol etabonate following ocular administration of a novel ointment formulation or a suspension (Lotemax ${ }^{\circledR}$ ) in rabbits with corneal inflammation. Invest. Ophthalmol. Vis. Sci. 51:1980, 2010.

46. Glogowski, S., Lowe, E., Siou-Mermet, R., Ong, T., and Richardson, M. Prolonged exposure to loteprednol etabonate in human tear fluid and rabbit ocular tissues following topical ocular administration of Lotemax gel, 0.5\%. J. Ocul. Pharmacol. Ther. 30:66-73, 2014.

47. Pflugfelder, S.C., Maskin, S.L., Anderson, B., et al. A randomized, double-masked, placebo-controlled, multicenter comparison of loteprednol etabonate ophthalmic suspension, $0.5 \%$, and placebo for treatment of keratoconjunctivitis sicca in patients with delayed tear clearance. Am. J. Ophthalmol. 138:444-457, 2004.

48. Villani, E., Garoli, E., Termine, V., Pichi, F., Ratiglia, R., and Nucci, P. Corneal confocal microscopy in dry eye treated with corticosteroids. Optom. Vis. Sci. 92:e290e295, 2015.

49. Jung, H.H., Ji, Y.S., Sung, M.S., Kim, K.K., and Yoon, K.C. Long-term outcome of treatment with topical corticosteroids for severe dry eye associated with Sjögren's syndrome. Chonnam Med. J. 51:26-32, 2015.

50. Barabino, S., Montaldo, E., Corsi, E., et al. The effect of tapered small dose steroidal treatment on symptoms, clinical signs, and ocular surface inflammation in patients with dry eye syndrome. Invest. Ophthalmol. Vis. Sci. 52:3826, 2011.

51. Rolando, M., Solignani, F., Valente, C., Allavena, F., Bertolotto, M., and Barabino, S. Is there a role for a long term tapered small dose steroidal treatment for keratoconjunctivitis sicca? Invest. Ophthalmol. Vis. Sci. 49:97, 2008.

52. Aragona, P., Aguennouz, M., Rania, L., et al. Matrix metalloproteinase 9 and transglutaminase 2 expression at the ocular surface in patients with different forms of dry eye disease. Ophthalmology. 122:62-71, 2015.

53. Wan, P.X., Wang, X.R., Song, Y.Y., et al. Study on the treatment of dry eye with loteprednol etabonate [in Chinese]. Zhonghua Yan Ke Za Zhi. 48:142-147, 2012.

54. Boynton, G.E., Raoof, D., Niziol, L.M., Hussain, M., and Mian, S.I. Prospective randomized trial comparing efficacy of topical loteprednol etabonate $0.5 \%$ versus cyclosporineA $0.05 \%$ for treatment of dry eye syndrome following hematopoietic stem cell transplantation. Cornea. 34:725-732, 2015.
55. Evans, D.G., Sheppard, J.D., and Williams, J.I. Loteprednol Etabonate Ophthalmic Gel $0.5 \%$ for Inflammation Associated with Dry Eye Disease: Outcomes Of a 12-Week Phase 2 Clinical Study. Presented at the Annual Meeting of the American Optometric Association; Washington, DC: June 21-25, 2017.

56. Sheppard, J.D., Scoper, S.V., and Samudre, S. Topical loteprednol pretreatment reduces cyclosporine stinging in chronic dry eye disease. J. Ocul. Pharmacol. Ther. 27:2327, 2011.

57. Singla, S., Sarker, L., and Joshi, M. Comparison of topical cyclosporine alone and topical loteprednol with cyclosporine in moderate dry eye in Indian population: a prospective study. Taiwan J. Ophthalmol. 9:173-178, 2019.

58. Lee, H., Chung, B., Kim, K.S., Seo, K.Y., Choi, B.J., and Kim, T.I. Effects of topical loteprednol etabonate on tear cytokines and clinical outcomes in moderate and severe meibomian gland dysfunction: randomized clinical trial. Am. J. Ophthalmol. 158:1172-1183.e1, 2014.

59. Ko, J.S., Seo, Y., Chae, M.K., Jang, S.Y., and Yoon, J.S. Effect of topical loteprednol etabonate with lid hygiene on tear cytokines and meibomian gland dysfunction in prosthetic eye wearers. Eye (Lond). 32:439-445, 2018.

60. Kheirkhah, A., Dohlman, T.H., Amparo, F., et al. Effects of corneal nerve density on the response to treatment in dry eye disease. Ophthalmology. 122:662-668, 2015.

61. Opitz, D.L., Evola, C., Paradesi, A., Okaj, E., et al. Efficacy of loteprednol etabonate ophthalmic gel $0.5 \%$ for the treatment of evaporative dry eye and meibomian gland dysfunction. Presented at the American Academy of Optometry. New Orleans, LA; October 7-10, 2015.

62. Novack, G.D., Asbell, P., Barabino, S., et al. TFOS DEWS II clinical trial design report. Ocul. Surf. 15:629-649, 2017.

63. Seitzman, G.D., and Lietman, T.M. Dry eye research-still regressing? Ophthalmology. 126:192-194, 2019.

64. Chalmers, R.L., Begley, C.G., and Caffery, B. Validation of the 5-Item Dry Eye Questionnaire (DEQ-5): discrimination across self-assessed severity and aqueous tear deficient dry eye diagnoses. Contact Lens Anterior Eye. 33:55-60, 2010.

65. Walsh, K., and Jones, L. The use of preservatives in dry eye drops. Clin. Ophthalmol. 13:1409-1425, 2019.

66. Kala Pharmaceuticals. Press release. Kala Pharmaceuticals receives FDA complete response letter for KPI-121 $0.25 \%$ NDA and plans to respond with data from STRIDE 3 trial. August 8, 2019. Available at: http://investors.kalarx.com/ node/7841/pdf Accessed September 11, 2019.

Received: February 5, 2020 Accepted: April 6, 2020

Address correspondence to: Dr. Kenneth Beckman Comprehensive Eyecare of Central Ohio 450 Alkyre Run Drive \#100 Westerville, $\mathrm{OH} 43082$

USA

E-mail: kenbeckman22@aol.com 